D O I : 10.15393/j9.art.2008.273

Т. Г. Мальчукова

Петрозаводск

\title{
АНТИЧНЫЕ И ХРИСТИАНСКИЕ ТРАДИЦИИ В ИЗОБРАЖЕНИИ ПУШКИНЫМ ПРИРОДЫ И ЧЕЛОВЕКА
}

(Опыт истолкования проблемы)

\begin{abstract}
Творчество Пушкина всегда находилось в центре внимания критико-философской мысли, как и филологической науки. Тем не менее ряд важных вопросов, связанных с его интерпретацией, все еще нуждаются в его пристальном и всестороннем изучении. К ним безусловно относится и основная для Пушкина проблема изображения человека и природы, которая стала темой нашего исследования, разумеется, не в полном объеме, а с точки зрения ее отношения к традициям античности и христианства. До сих пор названные традиции изучались раздельно и локально, в связи с отдельными реминисценциями в так называемой антологической поэзии или в духовной лирике Пушкина.

По нашим наблюдениям, присутствие этих основополагающих для европейской культуры традиций в тексте и подтексте сочинений Пушкина более универсально. В этой работе мы попытаемся рассмотреть значение античной и христианской традиций для изображения Пушкиным человека и природы.

В изображении поэтом весенней и летней природы обнаруживаются традиции античной идиллии, горацианской лирики и философской поэзии Лукреция, в некоторых
\end{abstract}

(C) Мальчукова Т. Г., 2008 
214

образах, в морских мотивах ощутимо влияние Гомера. Традиции христианской культуры, в первую очередь переложений псалмов, выступают у Пушкина в его вселенских, космических и горных пейзажах, а также в образах света, чувствах радости и любви, проникающих его изображение скромной, подчас скудной северной природы. Иногда античные и христианские образы выступают вместе. Так, в шуме моря поэт слышит «шепот Нереиды, / Глубокий, вечный хор валов, / Хвалебный гимн Отцу миров» ${ }^{1}$.

В мировоззрении поэта сосуществуют антропоцентрическая и теоцентрическая концепции. Антропоцентризм, во всяком случае эстетически, заявлен в стихотворении «Буря». Вместе с тем мир природы изображается Пушкиным как чудесное создание Бога, где «каждое дыхание хвалит Господа». Поэты, пророки вдохновлены Богом, их жизнь хранима Провидением. Но и жизнь всех людей в значительной степени определяется «случаем», «мощным, мгновенным орудием Провидения» (XI, C. 100).

В истолковании человеческих характеров Пушкин использует богатую этологическую традицию античности, представление о постоянстве характера, но и нарушающие его примеры и образцы. Однако решающее значение для представления Пушкиным различных характеров и судеб имело христианство с его изображением «внутреннего» человека, культурой исповеди, пониманием противоречивой сложности человеческой души, борьбы в ней добра и зла, способности к неожиданным поступкам, к преступлению, к греху, но и к раскаянию, прощению, милосердию, преображению и обожению.

Античные и христианские традиции в понимании человека, его характера, поведения и судьбы 
рассматривались нами на примере пушкинского романа «Евгений Онегин», в котором, по наблюдениям исследователей, около 600 персонажей, целая энциклопедия характеров. Здесь присутствуют и античные мифологические образы богов и героев: Зевс, Венера (Киприда), Диана, Эол, Морфей, Муза, вакханка, нереиды, дриады, киклопы, Приам, Парис, Менелай, Елена, Автомедон, Орест (Атрид), Пилад. И названы многие деятели античной истории и культуры: Ромул, Регул, Катон, Цезарь, Брут, Митридат, Гомер, Эсхил, Феокрит, Эпикур, Лукреций, Цицерон, Вергилий, Гораций,

${ }^{1}$ Пушкин А. С. Полн. собр. соч.: В 19 т. М., 1994-1997. Т. VI C. 167. Далее цитаты из произведений Пушкина даются по этому изданию с указанием в тексте тома и страницы.

Овидий, Сенека; их жизнь и личность, поведение, речи, философия были достаточно известны образованному читателю из «Сравнительных жизнеописаний» Плутарха, биографий поэтов у Светония, из их собственных сочинений, из их образа-репутации в европейской культуре.

Классический принцип постоянства характера, заявленный в античной словесности и теоретически (Аристотель «Поэтика». 15, 1454a 19-21; Гораций «Поэтическое искусство», 125-127), и представленный практически в литературных памятниках («Характеры» Феофраста, персонажи-маски в новоаттической комедии Менандра и в римских комедиях Плавта и Теренция), реализован у Пушкина в изображении сатирических типов московского общества и петербургского света. Психологию любви, «стратегию и тактику» любовного кокетства - «науку страсти нежной, которую воспел 
Назон» (VI, C. 8), поэт излагает в соответствии с поэмой Овидия «Ars amatoria» ${ }^{2}$. Очерк разнообразных людских склонностей в XXXVI строфе четвертой главы своего романа он дает по Горацию («Оды», I, 1). Горацианскую идею летящего, всеизменяющего времени («Оды», I, 11; II, 16) русский автор соединяет с наблюдениями возрастной психологии, впервые представленными в «Риторике» Аристотеля, и таким образом создает в своем романе изменяющиеся со временем характеры Прасковьи Лариной и Зарецкого.

В изображении центральных героев романа, Ленского и Татьяны, нами впервые были отмечены гомеровские реминисценции. Казалось бы, что может быть общего у романтического поэта и гомеровского Ахилла? Ничего, кроме указанного поэтами двоякого жребия: либо героических подвигов и ранней смерти со славой, либо жизни долгой, мирной и бесславной. Двоякое предсказание Ахиллу («Илиада», IX, 410-416) Пушкин трансформирует в представление двух возможных судеб Ленского (если бы его жизнь не была прервана нелепой дуэлью), данных, естественно, с современными историческими и культурными реалиями. В окончательной редакции романа автор говорил о возможной для Ленского славе поэта. Но в начальном варианте речь шла о военных подвигах или героическом восстании против царской власти: назывались имена Кутузова, Нельсона и Рылеева. В связи с последним напомним,

\footnotetext{
${ }^{2}$ Cм.: Albrecht M. De recentioris aetatis poetis Torquato Tasso, Volfgango Goethe, Alexandra Pushkin Artis amatoriae Ovidianae imitatoribus atque censoribus. Vox Latina, VL. 17, 1981.
} 
что в поэме Гомера говорилось о конфликте с царем Агамемноном героя Ахилла, защищавшего права ахейского войска. В пятой главе романа Пушкин в порядке шутливого состязания с Гомером сопоставляет его Елену со своей Татьяной:

\section{Но Таня, присягну, милей \\ Елены пакостной твоей.}

(VI, C. 650)

Однако в этом состязании-отталкивании был и положительный момент освоения гомеровских мотивов. Известно, что Гомер описывает не внешность Елены, но впечатление, произведенное ее «божественной красотой» на троянских старцев, готовых простить ей горести троянской воины («Илиада», III, 154-160). Отсылку к этому месту «Илиады» находим в XXXVIII строфе пятой главы:

Хоть вкруг почтенного Приама

Собранье стариков Пергама,

Ее завидя вновь решит:

Прав Менелай и прав Парид...

(VI, C. 650)

Заметим, что Пушкин тоже не дает портрета Татьяны (в отличие от портрета ее сестры Ольги), но зато подробно описывает впечатление, которое она производит в большом петербургском свете (VI, C. 171172). Примером в адаптации гомеровского приема к современному материалу был для Пушкина Вальтер Скотт, который использовал гомеровский мотив при описании героини «Эдинбургской темницы» Эффи Динс - сначала в шотландской деревушке, а затем в высшем свете. Пушкинское упоминание оценок «в высоком лондонском кругу» является реминисценцией английской вариации гомеровского мотива. 
Но главное в образе Татьяны связано не с античной, но c христианской традицией понимания «внутреннего человека», богатства духовного мира, сложной человеческой души, борьбы в ней разных чувств, добра и зла, лабильности человеческого характера, способности к неожиданным поступкам, к изменению, развитию, преображению. Эти свойства человеческой природы открылись Пушкину при изучении Евангелия, святоотеческой литературы, житий святых, как и в процессе самопознания, и затем были объективированы в образах близких ему героев и героинь. Так, его Татьяна способна на неожиданные поступки. Воспитанная на французских романах, она вместе с тем знает и любит народный быт и культуру. «Дика, печальна,

молчалива, / Как лань лесная, боязлива», она первая объясняется в любви Онегину. Любящая и отвергнутая, она, однако, не затворяется в одиноком горе, но по настоянию матери выходит замуж. Провинциальная девушка вдруг становится образцовой хозяйкой аристократического салона. Для многих читателей романа, например для П. А. Катенина, переход от провинциалки к светской даме казался неожиданным, слишком поспешным, что Пушкину было известно (VI, C. 197). Но для поэта и его героини есть супернатуральная логика преображения, чуда, и этой логике характер Татьяны соответствует. Продолжая любить Онегина, она отвергает его любовь, самоотверженно храня верность своему долгу.

Присутствуют в характеристике Татьяны и такие черты православного мирочувствия, как любовь к «малым сим»: она «бедным помогала», она привязана к няне, помнит о ней и умершей, вспоминает «смиренное кладбище, / Где нынче крест и тень ветвей / Над бедной нянею моей» (VI, 
C. 188); ее слезы: «И тихо слезы льет рекой» (VI, С. 185); ее простота, тихость, смирение: «Все тихо, просто было в ней» (VI, C. 171). Можно, думается, вполне согласиться с Достоевским $^{3}$ и следующим ему А. Позовым ${ }^{4}$ в том, что пушкинский «Татьяны милой идеал - идеал христианской любви, смирения, самопожертвования».

Большое значение для осмысления Пушкиным судьбы человека в мире имеет притча Христа о блудном сыне. Рассказанная, согласно Евангелию от Луки (Лк. 15:1132), после двух других притч о заблудшей овце (Лк. $15: 4-7)$ и о потерянной драхме (Лк. 15:8-10), она имеет прежде всего сотериологический смысл: речь идет о спасении грешников. А если иметь в виду движение символического сюжета, то в ней представлены апостасия человека (и человечества) от Бога, жизнь в грехе, раскаяние и возвращение к Небесному Отцу для спасения в вечной жизни 5 . Но и ее буквальный, земной, моральнорелигиозный смысл

\footnotetext{
${ }^{3}$ Достоевский Ф. М. Пушкин А. С. (Очерк). Произнесено 8 июня в заседании Общества любителей русской словесности. Дневник писателя на 1880 год. Август. Глава вторая // Достоевский Ф. М. Полн. собр. соч.: В 30 т. Т. 26. С. 141-143.

${ }^{4}$ Позов А. Метафизика Пушкина. М., 1998. С. 43-78.

${ }^{5}$ См. Святоотеческие толкования притчи о блудном сыне, как и богословские ее разъяснения в духовных журналах XIX века в кн.: Сборник статей по истолковательному и назидательному чтению Четвероевангелия / Сост. М. Барсов. 2-е изд. СПб., 1893. Т. 2. C. $186-201$.
}

\section{8}

чрезвычайно богат. Перед нами архетипические образы отца и сына, родного дома и чужого мира, контрасты праздности и труда, противоположность законопослушного и своевольного характера, вечная история заблуждений юности, антитезы справедливого 
воздаяния по закону талиона и милости, наказания и прощения, ненависти, зависти, гнева и любви к ближнему - закона и благодати. Наконец, в притче о блудном сыне знаменательно сливаются идеи возвращения-возрождения («брат твой сей был мертв и ожил, пропадал и нашелся» - Лк. 15:32), которые могут реализоваться как в сотериологическом, так и в буквальном, антропологическом, биографическом и религиозно-культурном плане. Последний аспект был заявлен уже в богословских толкованиях, по которым заблуждения младшего сына - это преданность соблазнам эллинской мудрости, а упреки старшего сына милосердному отцу и зависть к младшему брату означают законничество книжников и фарисеев и их ненависть, презрение к мытарям и грешникам, как и в целом противление иудеев, иудаизма Христианству ${ }^{6}$.

Притча о блудном сыне привлекает творческое внимание Пушкина с середины 1820-х годов. В пушкиноведении $^{7}$ отмечены такие реминисценции: полушутливое упоминание в личном применении в письме Вяземскому от 27 мая 1826 года (XIII, C. 279), отсылка в лирическом стихотворении «Воспоминание в Царском Селе» 1829 года (III, С. 189) и описание картинок на этот сюжет в повести «Станционный смотритель» 1830 года, перенесенное сюда из более раннего прозаического опыта Пушкина «Записки молодого человека» (VIII, C. 99-100, 404).

Согласно нашим наблюдениям, воздействие евангельской притчи на творчество Пушкина много шире; актуализация ее значения отнюдь не сводится к реминисценциям буквального сюжета, но включает и символические смыслы в сотериологическом и культурно-историческом аспектах.

Среди сложного комплекса образов и мотивов притчи о блудном сыне Пушкину, много скитавшемуся, лично 
была особенно близка идея возвращения на родину. В лирическом

\footnotetext{
${ }^{6}$ Там же. С. 187.

${ }^{7}$ См. $\quad$ указатель Н. В. Измайлова в $\quad$ изд.: $\quad$ Пушикин А. C. Полн. собр. соч.: В 19 т. М.: Воскресенье, 1997. Т. 19. С. 144; То же в кн.: Юрьева И. Ю. Пушкин и христианство. М., 1998. С. 264.

освещении мы встречаем этот мотив впервые в стихотворении 1829 года «Воспоминания в Царском Селе». Посещение Царского Села и Лицея после десятилетнего перерыва в мае 1829 года сравнивается с возвращением в отчий дом блудного сына:
}

Так отрок Библии, безумный расточитель, До капли истощив раскаянья фиал, Увидев наконец родимую обитель, Главой поник и зарыдал.

(III, C. 189)

Идея возвращения - возрождения воплощается в форме и содержании стихотворения, повторяющего строфу и варьирующего тематику лицейских «Воспоминаний в Царском Селе»: описание памятников русских побед и воспоминания о войне 1812 года.

В октябре 1830 года Пушкин написал загадочноаллегорическое стихотворение «В начале жизни школу помню я», вызвавшее множество различных интерпретаций. Нам ближе всех его толкование митрополитом Антонием, согласно которому школа и ее учительница - «это наша Святая Русь, чужой сад Западная Европа; два идола в чужом саду - это два основных мотива западноевропейской жизни - гордость и сладострастие, прикрытые философскими тогами», «я» - это и сам Пушкин, и «русское интеллигентное юношество» 8 . Подтверждают это понимание и 
замеченные нами ассоциации с притчей о блудном сыне, которая, согласно религиозно-культурной еe интерпретации, в заблуждениях младшего сына изображает его увлечение эллинской мудростью, составившей основу новоевропейской культуры, начиная с Ренессанса.

Образы-архетипы притчи о блудном сыне Пушкин тонко варьирует, почему они и не были узнаны прежде. В его стихотворении присутствует не милосердный отец, Господь Наш и Спаситель, а «смиренная, одетая убого, / Но видом величавая жена» с небесной строгой красотой и правдивыми речами - Богоматерь и Православная вера; показан не младший сын, но один из множества детей человеческих; представлен не один уход в чужую землю, но частые обращения к чужой культуре, лишенной света христианства:

\footnotetext{
${ }^{8}$ Митрополит Антоний (Храповиикий). Пушкин как нравственная личность и православный христианин // А. С. Пушкин: путь к Православию. 2-е изд. М.: Отчий дом, 1999. С. 200.
}

$$
\begin{aligned}
& \text { И часто я украдкой убегал } \\
& \text { В великолепный мрак чужого сада. } \\
& \text { (III, C. 255) }
\end{aligned}
$$

Несколькими определениями и характерными мотивами поэт устанавливает связь собственной картины с образом роскошной и праздной, но внутренне бедной и неспокойной жизни блудного сына в чужой земле: «...там нежила меня теней прохлада...»; «и праздномыслить было мне отрада»; «безвестных наслаждений темный голод / Меня терзал - уныние и лень / Меня сковали», «...я молча целый день / Бродил угрюмый - все кумиры сада / На душу мне свою бросали тень» (III, C. 255). Точными, яркими чертами обозначена классически- 
ренессансная культура «чужого сада»- искусство, философия, поэзия, наука: «...свод искусственный порфирных скал», «и белье в тени деревьев кумиры, / и в ликах их печаль недвижных дум. / Bce мраморные цчиркули и лирыз» (III, С. 254-255).

В пушкинском стихотворении не представлено возвращение блудного сына в родной дом, но возможность его дана осуждающей оценкой чужой религии: «То были двух бесов изображенья», «Сомнительный и лживый идеал - / Волшебный демон - лживый, но прекрасный», как и указанием на пока еще непонятые смыслы, превратно истолкованные правдивые слова родной веры и культуры. В незаконченности пушкинского стихотворения содержится историческая правда: возвращение русской интеллигенции к национальной традиции - не данность, а религиозно-культурная задача, актуальная по сей день.

Свое же собственное возвращение к национальной почве Пушкин в это же самое время, болдинской осенью 1830 года, обозначил выразительным литературным жестом: написанием повестей на сюжеты современной русской жизни от имени Ивана Петровича Белкина, образованием своим никак не связанного с западной культурой, но воспитанного в русской традиции, религиозно-православной и народнопоэтической.

В 1834 году Пушкин пишет стихотворение «Пора, мой друг, пора! покоя сердце просит» о возвращении на родину - «в обитель дальнюю трудов и чистых нег». Судя по плану этого незаконченного стихотворения, евангельская

\footnotetext{
${ }^{9}$ «Прохлада» на языке Пушкина имеет, наряду с современным, также и архаическое значение: «прохлады»- пребывание в неге, праздности. См.: Словарь языка Пушкина: В 4 т. М., 1959. Т. 3. C. 860. Курсив в цитатах А. С. Пушкина мой.
} 
идея возвращения понималась здесь и реально биографически, и в сотериологическом плане:

Юность не имеет нужды at home, зрелый возраст ужасается своего уединения. Блажен, кто находит подругу - тогда удались он домой. О скоро ли перенесу я мои пенаты в деревню - поля, сад, крестьяне, книги; труды поэтические семья, любовь еtс. - религия, смерть (III, С. 941).

Жизнь Пушкина сложилась в это время так, что вернуться в родное Михайловское ему не удалось. Возвращение же на духовную свою родину осуществилось у поэта мысленно, в молитвенном обращении к Богу, в частом повторении, в творческом воплощении великопостной молитвы Ефрема Сирина о духовном возвращении - возрождении. Она-то «неведомой силой» укрепляла его, «падшего», в последний год его жизни до христианской его кончины ${ }^{10}$. По духовному завещанию Пушкина тело его было погребено в Михайловском, в Святогорском монастыре.

В последнее семилетие своей жизни Пушкин многократно обращался к сюжету и идеям о блудном сыне и в объективных формах своего творчества - в повести и драме. Первым опытом освещения современного события или событий в свете евангельского рассказа стали начатые, но не законченные Пушкиным «Записки молодого человека». В начальном эпизоде молодой офицер останавливается на почтовой станции и в ожидании лошадей рассматривает картинки на стенке почтовой избы, иллюстрирующие библейскую историю блудного сына. Иллюстрации сопровождались немецкими стихами, которые молодой человек записал; вероятно, он вспомнил бы о них при сходных обстоятельствах. Параллелизм здесь был бы возможен: по сохранившемуся 
плану произведения в конце предполагалось возвращение героя на «родину» (VIII, C. 951). Оставив этот замысел, Пушкин перенес описание иллюстраций к библейской притче в повесть «Станционный смотритель» и сместил акценты в сюжете начального эпизода: не проезжий молодой человек, но станционный смотритель стал героем его повести.

В современной Пушкину литературе фигура смотрителя почтового тракта оказалась неожиданно популярной.

\footnotetext{
${ }^{10}$ Наши наблюдения могут послужить дополнением к рассмотрению этой темы архиепископом Никанором в «Беседе в Неделю блудного сына, при поминовении раба Божия Александра (поэта Пушкина), по истечении пятидесятилетия по смерти его» (А. С. Пушкин: путь к Православию. М.: Отчий дом, 1999. С. 238268).
}

222

В повести В. Карлгофа «Станционный смотритель» и сам смотритель представлен просвещенным философом, удалившимся с супругой от суеты столицы, и жизнь его - настоящей идиллией. Напротив, В. Булгарин в романе «Иван Выжигин» в стиле гротеска плутовского жанра изобразил смотрителя в самых черных красках. В стихотворном путевом дневнике «Станция» Вяземский противопоставляет неудобства езды по России приятным воспоминаниям о жизни и езде в Польше (обеды, жена или дочка смотрителя - кокетливая красавица-полька и т. д.). Пушкин все эти произведения современной литературы знает и ведет с ними через рассказчика повести - любителя литературы титулярного советника А. Г. Н. - полемический диалог: смотритель почтовой станции не «диктатор», как у Вяземского, а «сущий мученик 14 класса», жизнь не идиллия, как у Карлгофа, а настоящая «каторга», наконец, смотрители - это не 
«изверги человеческого рода», какими представил их Булгарин, а «люди мирные, от природы услужливые, склонные к общежитию, скромные в притязаниях на почести и не слишком сребролюбивые» (VIII, C. 97). Но главное, Пушкин свой рассказ о «бедных и несчастных» смотрителях переводит из плана современной литературы и социальной критики в план бытийственный, обращаясь к вечным темам семьи и религии, любви и смерти.

Переключение достигается смело и просто. В традиционном изображении жилища смотрителя Пушкин заменил описание картин как деталей интерьера, свидетельствующих о достатке и вкусе их обладателя, картиной символической, связанной с дальнейшими событиями. Это и были, напоминаем, картины, иллюстрирующие историю блудного сына. Исследователи заметили, однако, что сюжетных соответствий между евангельской притчей и «историей дочери», как она рассказана у Пушкина, нет: Дуня не берет денег у отца, не тратит его состояние и не возвращается домой. На наш взгляд, это неудивительно, ибо Пушкин не любил прямолинейных соответствий, а заблуждения дочери иного рода, чем заблуждения сына. Отход от прямого параллелизма, обобщая образ своевольной и заблуждающейся юности (аллегорически греховного человека и человечества), выдвигает на первый план фигуру отца с проблемами наказания и прощения, кары и милости.

С другой стороны, замена истории блудного сына историей соблазненной дочери связывала пушкинскую повесть с вечной трагической темой мировой литературы и давала

возможность писателю представить драму и поступки героев, а читателю их оценить на сравнительном фоне, И 
здесь мы видим, что, в отличие от многих отцов, Самсон Вырин не мстит соблазнителю и не проклинает дочь. Он идет в Петербург, чтобы умолять Минского вернуть ему Дуню, но Минский отказывается с ней расстаться, хочет расплатиться деньгами, грубо выгоняет отца. Вырину советовали жаловаться, но он махнул рукой и вернулся на свою станцию. Можно объяснять это его социальной приниженностью и слабостью характера. Но нельзя не признать его поступки и чувства христианскими. При всех страхах за дочь он чувствовал, что она не может быть счастлива без своего гусара, и жертвовал собой.

Рассказ о судьбе Самсона Вырина Пушкин включил в «Повести Белкина». Как и сам Белкин, его персонажи - в отличие от демонических героев романтической литературы - люди обыкновенные и скромные. Станционный смотритель среди них - самый смиренный, последний в социальной иерархии, «сущий мученик 14 класса». Несчастную свою судьбу он принимает с покорностью и смирением («от беды не отбожишься»), не мстит и не проклинает. Похороненный на бедном кладбище, в безымянной могиле без памятника, осененной одним черным крестом с медным образом, прощающий и смиренный Самсон Вырин должен быть прощен за свои грехи и помилован для вечной жизни на небесах. В это верят, на это надеются его молитвенники на земле: его дочь Дуня, любящая отца, но покинувшая его из-за любви к возлюбленному и к своим детям и теперь искупающая вину в молитвах и молебнах за упокой его души, и его друг, рассказывающий печальную повесть о его жизни.

Рассказчик повести, титулярный советник А.Г.Н., тоже имеет смиренное сердце. Будучи чиновником 9го класса, он не презирает младшего чином Самсона Вырина и даже предпочитает его общество и беседу «речам какого-нибудь чиновника 6 класса, следующего 
по казенной надобности» (VIII, C. 98). Православный по вероисповеданию, умудренный опытом жизни и собственной бедностью, он проникся христианскими идеями сострадания к «малым сим» и принял в сердце евангельскую мудрость, возможно, и при самостоятельном чтении Нового Завета, о чем говорит пример из Евангелия от Луки (Лк. 14:8-11), примененный им к рассуждению о званых обедах, как и точное знание евангельского текста при описании картин на

224

сюжет истории блудного сына. Он старше писателя Белкина и поэта Пушкина примерно на 15-20 лет (к моменту рассказа, спустя несколько лет после начала событий в 1816 году, он уже двадцать лет ездил по российским дорогам) и в своих жизненных привычках и в литературных вкусах несколько старомоден. Но чувства А. Г. Н. к бедному смотрителю несомненно разделяют и Белкин, и Пушкин: текст повести не содержит здесь ни малейших признаков дистанцирования от позиции повествователя и образа автора.

Так в пушкинской повести «Станционный смотритель» впервые в светской русской литературе появляется евангельский образ одного из «малых сих», показанный с христианским состраданием. Включив ее в «Повести Белкина» - свой первый опубликованный опыт национальной русской прозы, Пушкин утверждал образ маленького человека как характерную ее тему и христианский гуманизм как определяюшую ее черту. Христианский гуманизм с его сочувствием смиренным и обездоленным резко отличался от антично-ренессансного гуманизма западноевропейской литературы, сочувственно изображавшей по большей части великих героев, благородных аристократов, буржуа - 
«естественного человека» в сентиментализме или даже богоборца, демонического злодея в Романтизме. По контрасту с собственной культурой хорошо понимали особый - христианский — гуманизм новой русской литературы ее западноевропейские почитатели. Выдающийся немецкий писатель XX века Т. Манн называл основанную Пушкиным классическую русскую литературу «святой».

Общие христианские нравственные идеи, как и образы из евангельской притчи о блудном сыне, встречаем еще в ряде произведений Пушкина, написанных как в ту же болдинскую осень, так и позднее. В трагедии «Моцарт и Сальери» как будто оживает образ старшего брата из притчи с его гневом на отца и завистью к младшему брату, помилованному отцовской любовью. Как и этот библейский персонаж, Сальери требует справедливого возмездия и, возмущенный, протестует против евангельского прощения и милосердия - христианской благодати:

Все говорят: нет правды на земле.

Но правды нет и выше.

(VII, C. 123)

В трагедии «Скупой рыцарь» отношения между отцом и сыном развиваются контрастно в сравнении с евангельской

притчей, и эта противоположность христианской религии и этики подчеркивается в заключительных словах Герцога:

Боже!

Ужасный век, ужасные сердца!

(VII, C. 120) 
Дон Гуан в трагедии «Каменный гость» ведет распутную жизнь блудного сына, а в «Пире во время чумы» повторяется его пир с блудницами и «ложными друзьями». В маленьких трагедиях Пушкина перед нами его «опыт драматических» изучений героев в духе ренессансного гуманизма: все (кроме Моцарта и Священника) гордецы, властолюбцы, обаятельные эпикурейцы и безбожники. Нет в этом мире ренессансного гуманизма христианских идеалов смирения, терпения, прощения и милосердия. Отсюда и трагические финалы драматических коллизий.

Противоположность евангельского завета милосердия и прощения - древнему обычаю кровной мести и библейскому закону воздаяния «око за око» Пушкин показывает в конфликте чеченца-мусульманина и христианина в поэме «Тазит» (1829-1830). В 1833 году, обратившись к сюжету драмы Шекспира «Мера за меру», где в самом названии формулируется закон талиона, Пушкин в поэме «Анджело» ${ }^{11}$ выдвигает христианский этос милосердия. Пушкинское произведение показательно заканчивается мольбой о прощении и прощением:

«Прости же ты его!»

И Дук его простил.

$$
\text { (V, C. 129) }
$$

Отмеченные нами реминисценции евангельской притчи о блудном сыне укрепляют пушкинскую этическую идею прощения, милости, характеризующую все его творчество - от лицейских «Воспоминаний в Царском Селе» до итогового «Памятника» ${ }^{12}$.

\footnotetext{
${ }^{11}$ Об отношении пушкинской поэмы к драме Шекспира см.: Захаров Н. В. Шекспир в творческой эволюции Пушкина. Ювяскюля, 2003. C. $144-257$.
} 
${ }^{12} \mathrm{O}$ милости и прощении в ценностном мире Пушкина см. нашу статью: Мальчукова Т. Г. Пушкин как национальный и политический мыслитель // Духовный труженик: А. С. Пушкин в контексте русской культуры. СПб., 1999. С. 262-293. 